\title{
Disclosing Professionalism Behaviour of Internal Auditor in Preventing Fraud By Using the Local Cultural Wisdom 'Longko' (A Case Study at Toraja Tribe, South Sulawesi, Indonesia)
}

\section{Natalia Paranoan ${ }^{1}$, Petrus Peleng Roreng ${ }^{1}$, Christina Jeane Tandirerung ${ }^{2}$, and Edmondus Sadesto Tandungan ${ }^{3}$}

${ }^{1}$ Department of Accounting, Universitas Kristen Indonesia Paulus ${ }^{2}$ Department of Management, Universitas Kristen Indonesia Paulus ${ }^{3}$ Department of Law, Universitas Kristen Indonesia Paulus

\section{Abstract}

Corresponding Author:

Natalia Paranoan

paranoannatalia@gmail.com

Received: 29 August 2018

Accepted: 18 September 2018

Published: 11 November 2018

Publishing services provided by Knowledge $\mathrm{E}$

(c) Natalia Paranoan et al. This article is distributed under the terms of the Creative Commons

Attribution License, which

permits unrestricted use and redistribution provided that the original author and source are credited.

Selection and Peer-review under the responsibility of the ICOI-2018 Conference Committee.
This study aims to disclose the behaviour of professionalism displayed by internal auditors in preventing fraud by using local wisdom and the values of the Torajanese culture, namely longko'. This study was conducted using the qualitative method of ethnomethodology. The professional behaviour of the internal auditors is measured by using dimensions: dedication in profession, social obligations, personal autonomy demands, belief in self-regulation of profession and community affiliation. The longko' culture was analysed with the dimension of kamalamburan (honesty) and the dimension of karapasan (harmony), two values that are prioritised and preferred by the Torajanese community. The results of this study were interpreted and revealed that internalising the long $\mathrm{ko}^{\prime}$ culture will control the internal auditor's professional behaviour in fraud prevention and generate a concept of professionalism for the internal auditor based on Torajanese culture in order to achieve a clean organisational governance from fraud.

Keywords: professionalism, internal auditor, fraud, Longko'

\section{G OPEN ACCESS}

\section{Introduction}

\subsection{Background}

Along with the rise of rapid competition in the business world, the risk of fraud within companies is increasing. This situation forces the possibility that many violations and irregularities will have major consequences that can harm many parties, namely the occurrence of fraud. 
Fraud is an action that occurs because of the opportunity to perform misstatements in financial statements and misstatements arising from the undue treatment of assets (Tuanakotta, 2016; Meliany, 2013 in Delfi, et al., 2014). Fraud poses a serious problem because it often involves an individual's attempt to hide, falsify, mislead, manipulate and alter the right and fair view to take unlawful gain at the expense of another (Abdullahi and Mansor, 2015). Acts of fraud may be the taking or theft of property or organisational assets and hiding, transferring or spending the asset. BPK states that it often finds fraud in Indonesia conducted by State-Owned Enterprises (BUMN) by way of accounting calculations that allegedly make reports showing the earnings received are greater than actual earnings, in order to get reward or bonus and show good performance, even though the taxes paid will be bigger (Sastiana, 2016). Fraud does not only take place in Indonesia but also in more developed countries. In the beginning of the second quarter of 2017, there was a case of fraud in British Telecom, Europe, whereby the performance of information was manipulated to obtain bonuses, as well as its internal auditors being accused of making fake invoices (Priantara, 2017).

The reasons for committing fraud are often triggered by pressure affecting the individual, rationalisation, or opportunity (Tuanakotta, 2009). Fraud will be committed if there is an opportunity where an individual has access to the asset or has the authority to regulate the control procedures that permit the conduction of the fraud scheme. Positions, responsibilities, and authorisations all provide opportunities for fraud. To maintain public trust within the quality of investigation in fraud prevention, professionalism becomes the main requirement for auditors in performing their duties. When an auditor's professional dimension level is higher, the auditor will be more professional (Dwi and Effendi, 2013). An auditor shows professionalism when he meets three requirements; skill, knowledge and character. Character shows the personality of a professional, which will manifest in his ethical attitude and actions. An auditor's ethical attitudes and actions are also influenced by his/her cultural values (Pasande, 2013, Rusdy, 2015). An auditor's professional behaviour is one part of the General Ethic Code of Indonesian Accountants, which consists of eight principles of professional ethics. These principles become the corner stone of professional ethical behaviour and regulate the implementation of professional accounting services. Because of this, it is necessary to internalise the cultural values of local wisdom in the internal conduct of auditors to prevent future fraud.

For the Torajanese people, longko's culture includes not only a strong emphasis on embarrassment and self-esteem, but also tolerance, which reflects the need for a person to be polite and respectful and not to embarrass other people. Especially 
in big family relationships, if one individual does something embarrassing, the entire extended family will be shamed. The culture of shame from the perspective of anthropology is often understood as a static, unproductive, lagging economy, and lacking absolute norms (Mead 1961: 458-511). Culture greatly influences individual behaviour, and at a certain level, individual culture influences an individual's life beyond more than mere behaviour (Dayakisni and Yuniardi, 2008; Paranoan N, 2014; Paranoan and Pasanda, 2016). Pasande's research (2013) found that the longko' culture, as a result of the internalisation of the various insights firmly held by the Torajan people, not only contained the values of honour, self-esteem and shame but also other positive values of spirit and work ethic. Kamalamburan (honesty) and karapasan (harmony) are both values that are esteemed by the Torajanese community. Because of this, the longko' culture is particularly relevant in relation to the nation's wider efforts to overcome the dangers of corruption through cultural approaches. Therefore, researchers use the value of local wisdom in the Torajanese longko' culture to uncover the professional behaviour of internal auditors in fraud prevention.

Various studies on auditors' behaviour and fraud are very common but most of the research is analysed based on the positivistic approach, according to Barizah, Bakar and Ahmad (2009), MacLullich and Sucher (2005) and Windsor and Warming-Rasmussen (2009). The topic of the behaviour of professionalism regarding internal auditors and fraud in this research will be analysed with a non-positivistic approach using the longko' cultural values within the greater Torajanese culture. The cultural influence of longko' is a strong influence on the philosophy of Torajanese life contained in the social system. As Pasande (2013) observes, longko' culture is particularly relevant in terms of overcoming the danger of corruption (especially within accounting fraud) through cultural approaches.

This study uses the perspective of the Torajanese culture as a basis for interpretation and to uncover the professional behaviour of internal auditors based on longko' cultural perspectives in the actor. The definition of the actor in this study is an internal auditor who works at BUMN companies in Makassar Indonesia, considering the many cases of fraud that have appeared in BUMN.

\subsection{Research problem}

The research problem within this study is how to interpret the internal auditor's professional behaviour in preventing fraud based on the perspective of local longko' wisdom values found within Torajanese culture. 
The purposes of this study are 1) to understand how the application of local wisdom found within the Torajanese culture relates to the concept of internal auditor professionalism in fraud prevention, as well as revealing the values of the wisdom within the Torajanese longko' culture and how this can associate with the professionalism of the internal auditors; and 2) to explore whether the elaboration of ethical codes - to include the cultural values and local wisdom of longko'as seen in Torajanese culturewill result in the concept of the professionalism of internal auditors.

\subsection{Urgency of the research}

The phenomenon of fraud and dissatisfaction regarding internal audit services has shown a significant percentage increase (Priantara, 2017). It is, of course, questionable whether this profession can still provide assurance to the company's financial statements because the internal auditor plays such an important role in controlling fraud, in accordance with its function to prevent fraud by attempting to eliminate the causes of said fraud. To maintain public trust regarding the quality of examination in preventing fraud, professionalism thus becomes the main requirement for auditors in performing their duties. Currently, fraud is rampantly increasing due to the low ethical and moral values prevalent in today's society, which have been affecting the professional behaviour of individuals in performing financial activities. Research by Dayakisni and Yuniardi (2008: 59) states that culture greatly affects not just the behaviour of an individual, but other intricate aspects of an individual's life. In practice, social norms always serve as guidance as well as indicators in assessing the behaviour of individuals or groups within their communities. The norms contain the values of wisdom within a local culture that people use to survive in an environment. Individuals who adhere to their local cultural wisdom will generally also have good control and influence in their communities (Thontowi, 2007). According to Pasande's research (2013) as well as that of Rusdi and Prasetyaningrum (2015), corruption can be overcome through a cultural approach. The philosophy of life for Torajanese people is full of positive values that cultured human beings would benefit from instilling, especially in avenues such as carrying out accounting activities in order to always put forward ethics and morals as well as prioritising public interest above personal interests, so that the behaviour of financial actors is less likely to be compromised. 


\subsection{Contribution of the research}

Theoretically, the results of this study are expected to contribute to the development of science and knowledge in the field of accounting, especially related to behavioural accounting and auditing and in the field of law and law enforcement related to fraud. In addition, this study is also expected to increase the insights of other investigators related to accounting literature on the professional behaviour of internal auditors in fraud prevention.

In practice, the results of this study are expected to contribute to the company, in both the public and private sectors, related to the professional behaviour of internal auditors and the increasing problem of employee accounting fraud, and how local wisdom can make a positive influence with regard to this. The results of this study can also be used as a consideration for the parties involved in determining the direction of policy within the implementation of local government (policy in the frontier of financial governance and law enforcement related to fraud), especially within the Regional Government of South Sulawesi Province.

\section{Literature Review}

\subsection{Fraud prevention}

Fraud is a general notion that is embraced in a variety of ways of human ingenuity to gain benefit from others through wrong doing. Cheating is a deliberate fraud, generally in the form of lies, plagiarism and theft. Fraud is committed to gain money and wealth, or to avoid payment, loss of services, or taxes and also secure personal or business interests. Before fraud occurs, there are some precautions that can be taken by the company. The prevention of fraud cannot be separated from the role of internal auditors in accordance with their function in preventing fraud by trying to eliminate the causes of the incidences of such fraud.

\subsection{Professionalism of the internal auditor}

To maintain public trust in the quality of investigation in preventing fraud, professionalism becomes the main requirement of auditors in performing their duties. Professionalism is an element of motivation that is attributed to a person in order to attain high performance in tasks. According to Arens (2009), developed by Hall R 
(1995), professionalism is the responsibility of the individual to behave better than just obeying the laws and regulations of the existing society. A professional is a person who 1) believes that his work is important (dedication to the profession); (2) provides services for the public (social obligation); (3) requires autonomy as a condition for their services (demands autonomy); (4) supports separate rules that differ from other professional rules (belief in self-regulation) and (5) is affiliated with other members of their profession (professional community affiliation). The five dimensions are described as dedication to the profession, social obligations, demands of personal autonomy, trust in the rules of the profession itself and community affiliation. Each dimension in the five dimensions of professionalism has the benefit of explaining professionalism in relation to the auditor (Kalbers and Fogarty, 1995).

\subsection{Longko' values in Toraja culture}

Toraja is located approximately $350 \mathrm{~km}$ from Makassar, the capital of South Sulawesi Province. Torajanese culture can be accumulated into Aluk sola pemali or Aluk 7777, which governs the behaviour of individuals and society in dealing with the Creator, fellow citizens (social), and other creatures. No one questions or denies the truth and validity of the teachings, along with their logic. They accept, believe, and live their lives with this reality every day. This is, of course, easy to understand because it is in line with the Torajanese understanding and knowledge of the nature around them at any given time. The principle of longko' included in the aluk sola pemali is an important concept governing the social life of the Torajanese individual. The Torajanese people strongly hold the idea of maintaining their culture (Palm, 1979: viii). According to Clifford Geertz, culture is defined as something semiotic that is spun into the webs of humanity in a dependant way. The webs then become the culture as an attempt to find meaning, and therefore something that requires interpretation (Geertz, 1973: 5).

These symbolic webs are not only found in the ceremonies of Torajanese people but also in the meanings of their respective views and speeches, something Volkman understands as a story they tell people about themselves (Volkman, 1985: 7, Geertz, 1973: 448). For a Torajanese person, in every action honour and longko' is at stake. Furthermore, the feeling of embarrassment implies a very deep relationship between a person and the group on which he or she depends to support his/her self-esteem. Shame is a moral feeling, and in this case shame concerns a person's failure to comply with the moral values that have been set by the culture to be achieved; therefore, he/she has failed to live up to the conception of moral worth which has been set out 
for them to achieve (Rawls, 1971:482). For the Torajanese people, longko'is the idea of shame and honour that makes a person "human". For the Torajanese, it is longko' that allows the world to keep on moving forward (de Jong, 2008: 177-181).

\section{Research Methods}

\subsection{Ethnomethodology: Basic understanding and selection of research methods}

This research uses a qualitative method with an interpretive paradigm. Qualitative researchers build knowledge of reality rather than pseudo or that which is simply visible from the surface. Truth will only be "true" if it is also in accordance with belief (Kamayanti, 2016). The interpretive paradigm considers that science is not objective and not free of value as long as the theoretical construction process involves humans. Humans have subjectivity, which consciously or not will unite and be involved in the process of science construction. Similarly, accounting is practiced not under vacuum conditions of the environment in which it is being practiced. Accounting is also shaped and practiced through a social construction process involving human beings, which will undoubtedly involve the local values of the environment, shaping the subjectivity of accounting practitioners and the business community.

Ethnomethodology is chosen because the researcher is interested in describing what the internal actors/auditors socially do rather than what they think, how they communicate and how they interact. The use of this approach will capture the meaning of reality within the organisation under study as fully as the context it covers (Ludigdo, 2007, p. 71).

\subsection{Site and informant}

The research was conducted at BUMN companies in Makassar and six internal auditors participated as informants. The informants are Torajanese to help reveal the professionalism of internal auditors within the longko' value of Torajanese culture.

In determining the informants, the research was conducted purposefully and used to determine which informants could be used to fulfil the requirements of obtaining valid data. Determination of the informants was carried out using the snowball sampling technique. 


\subsection{Data collection and data analysis techniques}

The research was conducted using the ethnomethodology method. Data collection was carried out through observation, in-depth interview and documentation, where the researcher was directly involved with the informants' daily activities in order to obtain valid data.

The data was analysed by Miles and Huberman (Sugiyono, 2011:92-99). The internal auditors' behaviours related to professionalism were measured using the dimensions of: dedication to the profession; social obligations; personal autonomy demands; confidence in self-regulation of profession; and community affiliation (Hall, 1995). The longko' culture was analysed using the dimensions of kamalamburan (honesty) and karapasan (harmony), which are the preferred values within Torajanese society (Pasande, 2013).

\section{Discussion}

This research involves six internal informant auditors of BUMN companies to find the meaning of professionalism, fraud prevention and the longko' principle in Torajanese culture.

\subsection{Work professionalism of the internal auditor}

Professionalism becomes a credibility owned by internal auditors, which is one of the keys to success in corporate supervision. Within the professional attitudes of internal auditors, there is an expectation to take some steps to anticipate and detect any possible deviation. The work place professionalism of an auditor is a very important attribute because it can contribute to optimal service for the user of said auditor for decision making. This professional attitude is indispensable, as an auditor has an obligation to comply with the fundamental principles or code of ethics that have been set for an accountant. Within the conduct of professionalism at work, an auditor must have spiritual intelligence in performing his duties, including cultural influences. The concepts used to measure the professionalism of public accountants cover five dimensions (Hall $R, 1995):$

1. Dedication to the profession, which is reflected by the use of knowledge and skills possessed. 
This attitude is the expression of total surrender to work, with work being defined as the purpose of life and not just as a means to an end. Total surrender needs a personal commitment, and the expected compensation is first and fore most spiritual satisfaction followed by material satisfaction.

The higher the auditor's professionalism, the more likely the prevention of fraud will be.

This reflects that the auditor's professional attitude must prioritise the code of ethics in order to carry out his duties responsibly and objectively, because an auditor who has the soul of professionalism will always encourage himself to work diligently and professionally. Professional auditors will maintain confidence in the quality of their audits if the financial statements and audit report results are a top priority. Not just for the professional value, but their quality of work serves as accountability if their boss or partner commits fraud, as it is easy to detect which auditor was responsible for the fraud this way. Attribution theory explains that individuals are motivated by the pleasant outcome of being able to feel better about themselves for doing something that they consider positive.

This is also expressed by the results of previous studies completed by Dwi and Effendi (2013) and Matarneh, Moneim and Nimer (2015), who said that the higher the level of professional dimension, the more professional the person is. The professionalism of a professional will become increasingly important if the professionalism is linked to his individual work.

2. Social obligation; namely, the view of the importance of a professional's role and the benefits obtained either by the community or by the professional because of the work.

The auditor who respects his profession will more likely be responsible for the best-case scenario of his social environment when he realises that his work will affect the social environment in which the financial statements are used.

3. Autonomy demands; namely, a view that a professional must be able to make his/her own decisions without pressure from the other side.

Even though the internal auditor works for the company in which he/she is employed, the auditor must perform the work with full independence by reporting what should be reported without pressure from the interested parties, especially from the company itself. It is not uncommon for us to hear of fraud by internal auditors such as profit bubbles, tax evasion, and so on, which are the result of pressures from the company. 
4. Belief in self-regulation; a belief that the authority who assesses the professional work is a fellow professional, and not an outsider who has no competence in the field of science and his/her work.

5. Professional community affiliation means using professional ties as a reference, including formal organisations and informal colleague groups as the main source of work ideas. Through this professional bond, professionals build their professional awareness. As a professional, the auditor has an obligation to meet specific rules of conduct, which help to formulate the ideal attitude of professionalism. The obligation stated above is a responsibility that is fundamental within the profession to establish the services offered. A professional person has a greater responsibility because it is assumed that a professional has the ingenuity, knowledge and experience to understand the impact of the activities performed.

\subsection{Longko' culture: Honesty (Kamalamburan) and harmony (Karapasan)}

One of the main social demands of the Torajanese people is the strong emphasis on being honest or kamalamburan as well as working and maintaining harmony or karapasan through appropriate action, based on social attitudes supported by the feelings of longko'. Honesty (kamalamburan) is an inherent attitude in a person that can mean sincerity, being straight-hearted, trustworthy, and abstaining from lying and cheating. Honesty is part of the high value system of self-esteem. For the Torajanese people, committing intentional fraud means feeling ashamed (longko'). Shame is the inner state of a person. Therefore, sanctions are not always external and do not necessarily require the presence of others (Piers, Singer, 1971: 50-52, 68). In this case, shame is born out of an awareness of the inability to meet certain moral standards or goals that have been determined to be achieved (Rawls 1971: 440-445). The internal auditor will maintain the attitude of professionalism in relation to his or her professional group, because the longko' culture is a moral coordinate system and serves as one of the reference orientations of the Torajanese society.

Longko'culture emphasises the importance of shame. Adjustments to the interests of the group become very important. Fraudulent acts will have a profound impact on the profession and will embarrass the group. Personal interests in many cases must succumb to the interests of the group, for the sake of karapasan, or peace and harmony. Longko' is the result of inner feeling and not just shame as a result of a mistake or wrong action, as understood by Mead. Thus, the longko' culture regarding external 
sanctions, according to Mead, is not always based on what others think and say, but also on the consciousness and vigilance born of one's self. Indirectly, the longko' culture births the work ethic in the form of diligence and hard work. Longko' culture provides motivation to enhance creativity and competence in various areas of life, due to cultural demands. Longko' culture is the power and source of motivation to do something to realise the good reputation and esteem of the actor.

\section{Conclusion}

The professionalism of internal auditors is the key to success in running a company; internal auditors who have the nature of professionalism will perform their duties well, including their duty to assist management in preventing and detecting fraud that occurs in the corporate environment. But the professional attitude of the internal auditors is not enough if it is not equipped with a culture of honesty, high ethics, and management responsibility to evaluate the risks and other factors that exist on the part of the perpetrator. Therefore, it is necessary to internalise the value of longko' culture, kamalamburan and karapasan within the attitudes of professionalism of internal auditors to prevent dishonesty in the company in order to achieve a clean organisational governance from fraud.

\section{References}

[1] Abdullahi, Rabiu, and Noorhayati Mansor. Forensic Accounting And Frauds Risk Factors: The Influence of Fraud Diamond Theory. The American Journal of Innovative Research and Applied Sciences. 1(5):186-192. 2015.

[2] Akenbor, C.O and Uwaoma Ironkwe. Forensic Auditing Techniques and Fraudulent Practices of Public Institutions in Nigeria. Journal of Modern Accounting and Auditing, ISSN 1548-6583. 2014.

[3] Azis N, Mangoting. Y, dan Lutfillah. Q. 2015. Memaknai Independensi Auditor dengan Keindahan Nilai-Nilai Kearifan Lokal Siri' No Pacce. Jurnal Akuntansi Multiparadigma. Vol.6 (1),April. Pp 145-156.

[4] Barizah, N., A. Bakar, dan M. Ahmad. 2009. "Auditor Independence: Malaysian Accountants. Perceptions". Journal of Business and Management, Vol. 4, (12) pp 129141.

[5] Dwi, C dan Effendi. 2013. Pengaruh Profesionalisme Akuntan Forensik Terhadap Kompetensi Bukti Tindak Pidana Korupsi (Studi Kasus di Badan Pemeriksa Keuangan 
dan Pengembangan Provinsi Jawa Barat).

[6] Dayakisni, T., dan S. Yuniardi. 2008. Psikologi Lintas Budaya: UMM Pess. Malang.

[7] De Jong, Edwin, 2008, Living with the Dead: The Economic of Culture in the Torajan Highlands, Indonesia, Nijmegen University Press, Nijmegen.

[8] Geertz, Clifford, 1973, The Interpretation of Cultures, Basic Books, Inc., New York.

[9] Kamayanti, A. 2016. Metodologi Penelitin Kualitatif Akuntansi. Yayasan Rumah Peneleh, Yogyakarta.

[10] MacLullich, K. K., dan Sucher, P. 2005. A Local Realisation Of Auditor Independence

[11] Construct In Poland: Counteracting 'Iron Curtain' Syndrome In Academic Writing. Critical Perspectives On Accounting. Critical Perspectives on Accounting, Vol. 16, No. 5, PP 593-612.

[12] Mead, Margaret, 1961, Cooperation and Competition among Primitive People, Beacon Press., Boston.

[13] Nooy-Palm, Hetty, 1979, The Sa'dan Toraja: A Study of Their Social Life and Religion, Vol. I, Organization, Symbols and Beliefs, KITLV, Leiden.

[14] Rawls, John, 1971, A Theory of Justice, Harvard University Press, Cambridge.

[15] Volkman, Toby, A., 1985, Feast of Honor: Ritual and Change in the Toraja Highlands, University of Illinois Press, Chicago.

[16] Waterson, Roxana, 2009, Paths and Rivers: Sa'dan Toraja Society in Transformation, NUS Press., Singapore.

[17] Paranoan. N. dan Tikupasang W. 2013. Traditional Accounting Practice in Toraja South Sulawesi. E-book. Reviving The Negledted Knowledge.

[18] Paranoan N. dan Pasanda E. 2014. Price Determination Based in Toraja Culture. Asian Journal of Public Affair. Vol 4 (3).

[19] Paranoan N. dan Pasanda E. 2017. Power Behind Price Determination in Torajanese. Journal Research of Financial and Accounting (JRFA). Vol 8(6).

[20] Pasande D.S. 2013. Budaya Longko' Toraja dalam Perspektif Etika Lawrence Kohlberg. Jurnal Filsafat. Vol 23.(2). Agustus.

[21] Priantara. D. 2017. Ketika Skandal Fraud Akuntansi Menerpa British Telecom dan PwC. Warto Ekonomi, Juni.

[22] Rusdi. M. dan Prasetyaningrum S. 2015. Nilai Budaya Siri'na Pacce dan Perilaku Korupsi

[23] Jurnal Indigenous Vol. 13, No. 2, November pp. 68-86. 
[24] Sastiana. 2016. Pengaruh Audit Forensik dan Profesionalisme Auditor terhadap Pencegahan Froud dengan Kecerdasan Spiritual sebagai Variabel Moderating (Studi Perwakilan BPKP Provinsi Sulawesi Selatan). Thesis. UIN Makassar.

[25] Shenkin.M dan Coulson. A. 2007. Accountability Through Activism: learning from Bourdieu. Accounting, Auditing and Accountability Journal. Vol.20 No 2, pp 297-317.

[26] Sugiyono. 2011. "Metode Penelition Pendidikan". Bandung: ALFABETA.

[27] Thontowi, J. 2007. Hukum Kekerasan dan Kearifan Lokal: Penyelesaian Sengketa di Sulawesi Selaton. Fustaka Fahima. Yogyakarta.

[28] Tuanakotta. T.M. 2009. Akuntansi forensik dan Audit Investigatif. Jakarta: Salemba Empat.

[29] Tuanakotta. T.M.2016. Mendeteksi Manipulasi Laporan Keuangan. Jakarta: Salemba Empat.

[30] Windsor, C., dan Warming-Rasmussen, B. 2009. "The Rise of Regulatory Capitalism And The Decline of Auditor Independence: A Critical And Experimental Examination Of Auditors' Conflicts Of Interests". Critical Perspectives on Accounting, Vol. 20 (2), pp. 267-288. 